Article

\title{
Personal Narratives of Illness: Redressing Madness in the Singaporean Fiction of Amanda Lee Koe
}

\author{
Hannah Ming-Yit Ho \\ English Studies Program, Faculty of Arts and Social Sciences, Universiti Brunei Darussalam, Jln Tungku-Link, \\ Gadong BE 1410, Negara Brunei Darussalam; hannah.ho@ubd.edu.bn
}

Received: 9 February 2019; Accepted: 1 April 2019; Published: 6 April 2019

check for updates

\begin{abstract}
Amanda Lee Koe's short stories (2013) redress the limited tolerance for the mad citizen-subject, whose subjectivity is obscured, if not erased, by medical prescriptions. Official and often state-sanctioned conceptualizations of the peculiar mind are grievously justified in behavioral manifestations deemed socially unacceptable. Koe's stories about idiosyncratic Singaporeans illustrate the way personal experiences - of memory loss, homosexual tendencies, and emotional self-expressions-are informed by, and in turn inform, the biopolitical regulation of Singaporean citizens rendered objects of biopower. In this way, her stories invite a meditation on the state, people and power. Foregrounding fractured and unorthodox characters, these stories serve to intensify individual voices articulated in personal narratives addressing affective experiences, including sadness culminating in loneliness. Furthermore, the stories attest to socially constructed norms instigating the repudiation and criminalization of sexual deviants. Significantly, they add to the "cultural apparatus" — which C.W. Mills defines as "the source of Human Variety—of styles of living and of ways to die"- by questioning the nation's ideological imperatives, including heterosexual norms, social insistence on mono-cultural marriages and state/family-endorsed medical intervention. Offering a critique of ideological state apparatus embedded within the power structures inherent to psychopathology, Koe's Ministry of Moral Panic challenges the established ways of viewing "Others" who are ostensibly "mad". Consequently, her stories mediate a broadening human experience, by calling for inclusivity amid the social rejection and insular treatment of afflicted subjects with alleged disorders.
\end{abstract}

Keywords: Singapore; madness; mental illness; homosexuality; depression

\section{Illness in Literature: The Case of Amanda Lee Koe's Ministry of Moral Panic}

Literature provides a significant avenue for counter-narratives about subjects effectually struggling against state prescriptive knowledge and epistemology, as it articulates socio-cultural factors underscoring "conflicting human needs, aspirations and values" (Szasz 1961, p. 117). In this light, ill conduct and ill feelings of discontentment admonished by the nation through state apparatuses (of which psychiatry as a medical institution does its bidding) complicate unequivocal notions of health and, vice versa, illness marking abnormality. Rather than health signified through normative behavior dictated by the ruling state, citizen-subjects' variety, complexity, and differentials of living constitute the vigorous social fabric of the nation. By revoking the tenuous label of psychic illness, literature thus plays an important role in resisting the objectivity of the diseased category ascribed to the socially suffering subject, in whom pathology acts as justification for state corrective measures. Along this line, I argue for the depathologizing of the mind, considering "disease" serves as a metaphor for social, cultural, and moral forces imposed on the subject under the purview of the scrutinizing state. To this end, Amanda Lee Koe's collection of short stories entitled Ministry of Moral Panic (Koe 2013) functions as a responsive text to challenge the view that modern-day living can be simply reduced 
to pathogens and chemical imbalances. Non-erudite scientific justifications based on presumptive diagnoses of the mind's disease betray political leanings and state agenda that ultimately rob the subject of any individual agency, as well as glossing over the psycho-social reasons for the subject's "ill" dispositions. Herein, the normalization of experiences, conditions, and feelings of individual subjects recalls the efforts of a segment of psychiatrists working to de-stigmatize mental illness and undo the wholesale use of illness to indicate decisive disease. However, at its best, the anti-psychiatry movement (led by psychiatrists themselves, including David Cooper, Ronald Laing and Thomas Szasz) falls short of dismantling the association between mental illness, with its intricate pathological underpinnings, and natural human experiences such as depression, dementia, homo-, bi-, and trans-sexual tendencies, and other emotional ailments. Failure at such disengagement and disconnection is attributed to the persistence of the mental illness term, which Moncrieff calls out as "unhelpful" (Moncrieff 2013) for presuppositions of interventionist medical treatment, including institutionalism and drug therapy in view of a "disease-centered" (Maisel 2016) approach to the afflicted mind.

At this point, I propose that Ministry of Moral Panic engages the medical humanities by offering a critique of the medical pathologization of the mind, with the aim to reassess the rhetoric used against subjects exhibiting behavioral symptoms that characterize an ill mind. In addition to natural biological factors such as aging, social factors are also in play when dealing with responses to embodied identity. Through intra-textual and contextual information provided by these short stories, the eccentric behavior and idiosyncratic traits of Singaporean subjects may be considered in terms of the wide spectrum of human nature, and the state's lack thereof to view it as such leading to distinctions of their different status. Koe's work illustrates Singaporeans negotiating with state power and, specifically, "biopower" (borrowing Michel Foucault's term). Insofar as biopower is the "explosion of numerous and diverse techniques for achieving the subjugations of bodies and the control of populations," (Foucault 1982, p. 140) then ideological state apparatuses and cultural forms of surveillance serve in oppressive forms to counsel the subject vilified for deviant "ill" conduct. To this end, Koe's literary writings contribute to discussions about the social and cultural circumstances giving rise to psychic conditions that demand their subjects to be "govern[ed]". ${ }^{1}$ If we take governing to entail "control[ing] the possible field of action of others" (Foucault 1978), then Koe's characters are curtailed not only by ideological state values, but also subjected to wider socio-cultural impositions at the individual level. In other words, the physical manifestation of peculiar conduct (deemed as subversive acts) are in contravention of national ideologies predicating the subject's "unfreedom" (Koe 2013, p. 157)—signaling the loss of human agency avowed by the state. Through further analysis, Koe presents new insights into the variegated identities of Singapore that allow for autonomous choices, instinctive drives, and natural life struggles. From this perspective, a psychiatrist's role in delivering state biopower when, wittingly or unwittingly, discounting the human aspect of the diagnosed psychic disease contributes to the subject's coercion into or complete deletion from the "official version of world reality" (Mills 1963) propagated by the state. This erasure of identity and non-agency testifies to the state's occlusion of the "core-essentiality" (Cooper 1989) of humanity, whereby the pseudo-medical categorization of the mind suppresses human nature by stifling any instinctive vocalization of self-identity at whatever its developmental stage. Furthermore, the emphasis Koe's stories place on interactional social pressures that result in the subject's lack of freedom in expressing an authentic (contrasted to conformist) self and identity serves the project calling for "the humanization of man in society" (Arnold 1961, p. 483)—where conflict and losses within the self and in interaction with others are accounted.

Consequently, I argue that Koe's short stories (2013) redress the limited tolerance for the mad citizen-subject, whose subjectivity is obscured, if not erased, by medical prescriptions. Official

1 "'Government' did not refer only to political structures or to the management of states; rather, it designated the way in which the conduct of individuals or of groups might be directed-the government of children, of souls, of communities, of the sick" (Foucault 1982, p. 341). 
and often state-sanctioned conceptualizations of the peculiar mind are grievously justified in behavioral manifestations deemed socially unacceptable. Koe's stories about idiosyncratic Singaporeans illustrate the way personal experiences - of memory loss, homosexual tendencies, and emotional self-expressions-are informed by, and in turn inform, the biopolitical regulation of Singaporean citizens rendered objects of biopower. In this way, her stories invite a meditation on the state, people and power. Foregrounding fractured and unorthodox characters, these stories serve to intensify individual voices articulated in personal narratives addressing affective experiences, including sadness culminating in loneliness. Furthermore, the stories attest to socially constructed norms instigating the repudiation and criminalization of sexual deviants. Significantly, they add to the "cultural apparatus" - which C.W. Mills defines as "the source of Human Variety—of styles of living and of ways to die" (1963)—by questioning the nation's ideological imperatives, including heterosexual norms, social insistence on mono-cultural marriages and state/family-endorsed medical intervention. Offering a critique of ideological state apparatus embedded within the power structures inherent to psychopathology, Koe's Ministry of Moral Panic challenges established ways of viewing "Others" who are ostensibly "mad". Consequently, her stories mediate a broadening human experience, by calling for inclusivity amid the social rejection and insular treatment of afflicted subjects with alleged disorders.

\section{Ministry of Moral Panic: Foregrounding a Minority Status}

A crucial concern in Koe's debut collection of stories is the plight of the disenfranchised and disempowered Singaporean, who is rendered incorrigible, isolated and at odds with the larger discourse of national identity. When asked about the complicated identities of her fictional characters, the author resorts to explaining the terms of her own Singaporean identity: "Growing up in Singapore it always felt urgent and necessary for me to define myself against the norm-which is shaped by national identity - and whilst I am aware that that is also the mainstay of every angsty teenager there ever was, this has never changed for me" (Sikuska 2016). What becomes apparent here is the critical juncture calling for the paving of life trajectories that have been little mapped because of their unconventional and unlawful nature. Along this line, Singapore's "nagging veil of pragmatism" (Koe 2016) underscores its patriarchal style of leadership (Low 2006; Heng and Devan 1995), leading to a stifling nanny state where the Singaporean government instructs and intervenes into personal matters of life. For Kenneth Tan, the government's "technocratic authority seeks to eliminate 'irrational' desires and the chaos of erotic instincts" (Tan 2003, p. 403). Similarly, for Eng-Beng Lim, the Singaporean father-state censures the "exotic sexuality [of] the global Asian queer boy" (Lim 2014, p. 92). A significant instantiation of the authoritative father-state lies in its persistent hardline resolve in refusing a repeal of the criminalization of sex between men in Section 377A of the Penal Code. "[O]ften justified as being consistent with the importance society places on family values" (Nair 2007), this section has yet to be repealed as parliamentary debates reiterate and underscore the dangers of normalizing homosexuality, that purportedly undermines "a stable society with traditional, heterosexual family values" (Lee 2007). As such, Oswin rightly points out the family's function as a "regulative governing fiction in the city-state" (Oswin 2014, p. 412). Even as the Singaporean government avoids enforcing Section 377A by declaring that "[d]e facto, gays have a lot of space in Singapore" and "gay bars and clubs [... ] do not have to go underground" (Lee 2007), which reflect the deeply ambivalent sentiments characterizing 377A (Wong 2016), the lack of a repeal remains a "constitutional problem" (Woon 2014). Meanwhile, at the grass-roots level, there have been great strides to gain inclusivity for homosexual citizens. For instance, the Pink Dot rally was started in 2009 by Singapore's gay community and gay parades are also licensed by the police. Furthermore, gay citizen-subjects fall short of being indicted, as Singapore's Law and Home Affairs Minister Shanmugan points out: "So, really, when was the last time someone was prosecuted?" (Ong 2018), while Prime Minister Lee Hsien Loong also makes clear that "The government does not act as moral policemen [a]nd we do not proactively enforce Section 377A on them" (Lee 2007). It is within this juxtaposition of having to toe the line and protesting against institutionalized homophobia that Koe's work is located. Navigating 
the communal areas of the university, school, pub, condominium, laundromat, local parks and national landmarks such as the Singapore Flyer and Merlion, the estranged women and emasculated men of Singapore's Chinese, Malay, Indian, and Others (CMIO) demographic inhabit the montage-like literary spaces of Koe's collected stories. In their heightened loneliness and physical state of being alone, these characters serve as a testament to the inherent struggles when moving away from the norms ascribed by the status quo. In writing about humans readily categorized as "weirdo[s]" (p. 73) ${ }^{2}$ and cast out to the social peripheries of the nation, Koe deals with the subversive exploration of Singapore's "Others". Even as the Singapore Arts Council is supported by the state ${ }^{3}$, the author puts forward the creative articulation of the "[distraught] blow of life" (p. 168) in the interplay between national and individual identity. The state's intervention and implicit influence in the lives of Singaporean subjects are apparent in the Ministry of Moral Panic, whose title alludes to the political manufacture of moral panic via ideological state apparatuses to admonish, punish, and regulate citizen-subjects who fail at conforming. Central identity motifs to be discussed include depression (causing and effecting loneliness) and homosexual relations deemed inappropriate. In all the stories, an accentuated sadness and acute feeling of individualized difference coupled with physical loneliness affect gendered subjects encountering socio-cultural, and other times racial, tensions while navigating the local and globalized spaces of Singapore.

Taking into consideration that "symptoms of mental illnesses contain some autobiographical meaning," (Dammann 1997, p. 735) then madness that is exemplified by the characters when exhibiting undesirable mental processes elicited in unacceptable behavior is informed by their specific social habitats. To go mad is to go against the expectations of normative behavior and thought-madness is ultimately measured against a normality. Madness is also used as a tool to segregate those afflicted by "an experience of unreason" (Foucault, p. 188), typically exhibiting "self-absor[ption]" (p. 25) too. Depression and homosexuality may be considered as forms of unreason or madness, as they represent a dissolution of thought and disturbance of mood that readily ascribe to the subject "a minority status, an aspect of itself that does not have the right to autonomy" (Foucault 1978, p. 239). As such, these different modes of madness fall within the broader term of mental illness, which Koe rebukes by exposing the flaws in psychiatric practices (in the story "Chick," the male psychiatrist takes sexual advantage of a schoolgirl younger than his own daughter), and revealing the futility and aggression of insipid institutionalism in the story "Siren". In Ministry of Moral Panic, there are additional instances of explicit expressions of sadness and depression in the story "Love is No Big Truth" and non-dysphoric depression in "Flamingo Valley," where depression is blurred with dementia. Additionally, homosexuality, debunked today as a kind of mental illness, is examined through lesbian liaisons in the stories "Alice, You Must be the Fulcrum of your Universe" and "The Ballad of Arlene and Nelly," and in the transsexual subject in "Siren". All in all, love and lost love shape the responses of Singaporean characters who are restricted by state-dictated norms, yet, to a certain degree, also exercise their self-articulations of their own problems in living.

\section{Depression: Lost Love, Social Abandonment and Subjective Gains}

The lack of love and, more specifically, intra-cultural constraints that limit the freedom to choose a spouse, contribute to the depressive state of affairs in both "Love is No Big Truth" and "Flamingo Valley". While the female characters in these stories exhibit symptoms of sadness, which the protagonist in "Love is No Big Truth" readily identifies as depression (p. 100), their disinterest and dysfunction in everyday living symbolize the interpersonal problems they encounter. And so, whilst "depression is one of the most common psychological conditions and is a normal part of living in view of the losses

\footnotetext{
All in-text page numbers in parenthesis are references to Koe's Ministry of Moral Panic, 2013.

Koe has been awarded two national accolades in the form of Singapore Literature Prize for Fiction 2014 and Singaporean Book Award for Best Fiction 2016.
} 
and disappointments that we all encounter at different stages of the life-cycle" (Lemma 1996, p. 72), the hypothetical line between depressed and non-depressed (Rippere 1994) as well as normal depression and disordered depression are tenuous. In "Flamingo Valley," the Chinese female protagonist rests in a nursing home where nurses constantly enquire "Have you taken your medicine yet?" (p. 13), thus readily alluding to prescribed drugs as part of what Moncrieff terms the disease-centered approach to treating the mind (2016). Ling Ko Mui is without past recollections, even as she miraculously recovers from muscular atrophy via the resumption of mechanical functions (p. 19) and overcomes her speech impediment (p. 13). Cultural expectations have restricted her from marrying her Malay ex-lover Deddy Haikel, now married into his own culture with three Malay wives. Similarly, in "Love is No Big Truth," heartbreak defines the female protagonist abandoned by her husband. As a result, the loss of love contributes to detachment, both physical and emotional. Such sadness culminating in loneliness is evident between estranged mothers and their daughters, with the latter failing to understand the emotional plight and condition of their mother because of broken and, frankly, impossible channels of communication- "[My daughter] started speaking to me in English, though we'd always spoken in Mandarin, though she knew I barely had a handful of English words" (p. 100). A breakdown in communication is also apparent in Ling Ko Mui's case, where both daughter and granddaughter are distraught because of her non-response to their calling her Ma (mother) and $\mathrm{Ah} \mathrm{Ma} \mathrm{(grandmother).}$ Coupled with a heightened sense of frustration, the daughters' disappointment contribute to the social isolation of their heartbroken mothers, deemed as a failure in their family even as the latter, in fact, is "the one who has been left behind" (p. 102). In the segregated space of the nursing home, Ling Ko Mui is forcibly absolved from her social roles, relations, and identity within her family. Afflicted with the joint symptoms of dementia and depression (Muliyala and Varghese 2010) or as the Malay descriptor nyanyuk suggests, the mental deterioration of Ling Ko Mui signals difference, which gives her family a reason to put her up in an institution under the long-term care of nursing staff. Consequently, lost love causes both female protagonists to exhibit sadness, but with a reasonable cause rather than without cause. In this perspective, ego-depletion that Freud identifies as a pathological indicator of depression elides them. Rather than an ego consumed and damaged by loss, the mothers show cognizance of the "truth of their irrevocably being "set free" (p. 102) from cultural limitations, familial relations and other such duties to "people in our lives" (p. 102). When stating emphatically, "I was independent of being a wife, a mother, even, a woman. I was simply me" (p. 102), the female protagonist indicates that loving herself has taken precedence over needing to love others. Along this line, a distinct blurring between healthy loneliness and sick loneliness is made. Thus, the protagonist-narrator's declaration that "loneliness is freedom" (p. 101) is neither delusional nor nonsensical. It illustrates a personal narrative of being wronged by society. Consequent channeling of the sadness attached to an existence within society into subjective gains effectively reframes social abandonment and loss.

With nursing homes and hospitals serving as backdrops, the threat of institutionalism for want of a nursing staff's, medical surgeon's or clinical psychiatrist's intervention at the demand of Singaporean society and the family is signaled. In terms of biopolitics, depressed subjects and sexual deviants are branded as social outcasts and relegated to the policed realms of medical institutions as a cautionary measure against citizen-subjects' irresponsibility when jettisoning familial duties. A conformity to the institutionalized normality denotes, for Koe's characters, that "life is difficult" (p. 124). Coming to terms with losses of individuality, freedom and memory, the female protagonists exemplify their agency in choosing a course of self-determined outcome, at least in terms of their renewed mindset. With the revelation that "love [defined in view of obligations to loved ones] is no big truth," Koe's protagonist decides for herself to "throw [away] the bed" (p. 100) and, thus, to decidedly jettison institutional prescriptions ascribed to her body. With "depression [being] easy when you have a bed" (p. 100), the protagonist rejects society's reduction of her subjectivity to the physical limits of a solitary bed. Rather than denoting rest and recovery, the bed acts as a metaphor for the convenient reduction of, and subsequent punishment for an inability to adapt to, a difficult life. However, the resumption of mental faculties loudly exemplifies their endurance and initial victory amidst continuing 
social isolation. In Ling Ko Mui's recovery of her speech even as, and precisely because, her daughter dismisses her words as gibberish whilst nurses completely understand her articulated words and her frame of references (p. 21), she shows evidence of a thinking subject despite not doing away successfully with the bed. In the story "Love is No Big Truth," the unnamed female protagonist decides to break free from "Entrapment" (p. 100) in exhausting relationships that have depleted her subjectivity rather than bolstered it. In these instances of the self-articulation and expression of agency, Koe poses human variety in terms of her protagonists' resistance, or at least active response to, the "slow careen towards certain death" (p. 13) in society's bleak designation of their institutionalized or segregated space of living.

In Ministry of Moral Panic, medical intervention by psychiatrists to cure "diseases" of depression, self-injury, and psychosis are misguided and prove futile as characters remain incorrigible after treatment. This foreclosure of medicinal and psycho-therapeutic solutions to mitigate subjects' illnesses underscores an aporia-whereby, healing declares itself to be a lie with little to no return to the promised site or destination of wholesome identity. If the goal is to return the subject to normative behavior deemed socially acceptable, then the healing fails miserably. Every effort to heal presents itself as an absurdity. Under the guise of the pastoral custodian, the ruling class attempts to hold the subject under close scrutiny, in arrested development, and subjected to inimical censorship. Healing, as a kind of reverse pathology, proves incongruous with "problems in living" (Szasz 1961) with no pathological sources, thus revealing itself as a disciplinary tool for state ideological apparatuses in which to seize the subject. Thus, intrapsychic conflict results from state ideology that promotes cultural norms, which in turn expose the ambiguous and equivocal frames of normality. To this end, the social meanings of mental illnesses, or social reasons behind idiosyncratic expressions, cannot be fully uncovered by "psychiatrists who have paid very little attention to the experience of the patient from the patient's point of view" (Laing 1964). Rather, the tendencies for depression and memory loss, as well as homosexual inclinations, are underscored by coercive demands for conformism that reinforce the conflict with, and within, bodies labeled different and deviant.

\section{Homosexuality: Subversion of State Narrative in the Assertion of Individual Subjectivity}

Perhaps the most contentious categorization of mental illness lies in the label of homosexuality, a prominent theme in identity politics not least due to the persecution, stigmatization and exclusionary practices faced by same-sex partners. Even as homosexuality is no longer listed as a mental illness since its removal from the DSM in 1987 and ICD-10 classification in 1992, disorders of neuroses and psychoses continue to be entailed by this term. Also, prejudice against homosexuals is very much prevalent as their sexual orientation and behavior are regarded as irresponsible conduct that deviates from the heteronormative standard. For practical reasons of determining biological reproduction, large sections of Asian society have politicized these subjects for their failure firstly, to procreate and secondly, for the infectious spread of social diseases, including the HIV epidemic that is traced back to them. There are those who prefer to hide beneath the veneer of a heterosexual marriage (at timed remaining unconsummated), and this instance articulates the desperate attempt to fit into society. From its evolving explanations from an act of sin (appropriated from pre-enlightenment Church), mental illness that supplants the narrative of the sinner with victim, to today's ICD-10 categorization of "ego-dystonic sexual orientation" entailing the way the subject "wishes [his or her] sexual preference $w$ [as] different because of associated psychological and behavioral disorders" (Burton 2015b), homosexuality continues to carry associations of the need for corrective measures. Prevalent diagnostic labels attached to gays (Silverstein 1996), lesbians and transsexuals signal the continued pathologization of non-heteronormative sexuality. Negative attitudes towards homosexuality also underscore the subject's "unnatural" status, even as increasing lobbying of homosexuality as an innate rather than 
immoral trait was visibly growing amongst Singaporean politicians. ${ }^{4}$ Even as conversion therapy is outdated and is not practiced in Singapore, the problems that gays, lesbians and transsexual subjects face in a nation modeling itself as one big family - with the government playing a paternal role and its people seen as daughters/children (Heng and Devan 1995)—are clearly accentuated by the traditional definitions of marriage as a heterosexual institution (Brooks and Wee 2011). Furthermore, Singapore's procreation policies, although aimed mostly at graduate Chinese women, also excluded homosexuals who found themselves unable to fit into the wider narrative of a nation intent on procreating children to increase the nation's gradually falling birth-rates (Kuah 2018).

Despite Singaporean politicians calling for inclusivity and tolerance through public defenses of homosexuality as an inherent biological trait attributed to the brain structure, ${ }^{5}$ the continuing outlawing of homosexuality underscores that its legality is neither here nor forthcoming. Amid ongoing controversies about sexuality, gender, the family and civil rights that take place within the nation-state (Mokhtar 2018; Detenber et al. 2014; Ong 2013; Lim 2004), there is increasing pressure placed on Singapore to break the stalemate in the repeal of Section 377A occasioned by India's Supreme Court striking down its Section 377 on 6 September, 2018. Singapore's state narrative defining "overall society [as] conventional, it remains straight" (Lee 2007) attests to an illiberal pragmatism on the government's part (Yue and Zubillaga-Pow 2012), even as the government has recently taken a more liberal stance on public expressions of homosexuality (Oswin 2014). In other words, the "Singaporeanness" (Yeoh 2006, p. 121) of citizens declaring themselves as homosexuals is compromised. While a recent research survey conducted by Nanyang Technological University (NTU) has indicated a small positive trend towards greater tolerance of homosexuals, public attitudes towards homosexuals remain mostly negative among Singaporean citizens and permanent residents (Detenber et al. 2012). Even as homosexuality is no longer internationally classified as a mental illness, the project to depathologize it continues, considering that prejudice against homosexuals are deep-seated. ${ }^{6}$ Same-sex couples are still addressed using a technical vocabulary that follows a medical paradigm (Laing 1965). Singapore's legal framework also denies them lawful marriage and notionally penalizes homosexual coupling (Singapore: Court Ruling a Major Setback for Gay Rights 2014). ${ }^{7}$ Banned under British rule for most of the nineteenth and first half of the twentieth century, and considered an unlawful deviation from normative heterosexuality, acts of homosexuality violate Section 377A of Singapore's Penal Code. The criminalization of sex between men is a British legacy that ultimately serves a political agenda. Through this legislation, the state's ideology of heterosexual normality is propagated for national prosperity. Moreover, courts increasingly seek mental health experts to testify in criminal cases (Gwee 2017). Promoting family values underlining the heterosexual norm, Prime Minister Lee Hsien Loong effectively proscribes homosexuality. He states, "Singapore is basically a conservative society. The family is the basic building block of this society. And by family in Singapore we mean one man, one woman, marrying, having children and bringing up children within that framework of a stable family unit" (Au 2009). As this example and others demonstrate, vicissitudes within politics ranging from support to rebuke of homosexuality, veiled or otherwise, reflect the contingent terrain treaded by Singaporeans in same-sex relationships.

Along this line, public views of homosexuality are both propped and shaped by legislation and policies that advocate heteronormativity. Debates within, and between, the public state and private

4 In the 7 July, 2003, issue of Time Asia, ex-PM Goh Chok Tong reportedly remarked, "So let it evolve, and in time the population will understand that some people are born that way. We are born this way and they are born that way, but they are like you and me" (Wayne and International Herald Tribune 2003).

5 On 1 December, 2002, Minister of State for Health, Balaji Sadasivan, also a neurosurgeon, declared, "Research has also shown that the brain of homosexuals is structurally different from heterosexuals. It is likely therefore that the homosexual tendency is imprinted in the brain in utero and homosexuals must live with the tendencies they inherit as a result of structural changes in the brain" (Sunday Times 2002).

6 In 2013, polls show that 75\% of the Singaporean population oppose same-sex sexual activity (Shen 2014).

7 On 29 October, 2014, The Singapore Supreme Court upheld the ban on same-sex activity between men by concluding, "There is, at present, no definitive conclusion [on the] supposed immutability [of homosexuality]." 
family units ensue, not least in view of the United Kingdom's decriminalization of homosexuality in its Sexual Offences Act in 1967. Here, such debates reveal a discord between Singapore's national, postcolonial and global discourses (Naruse and Gui 2016, p. 474) that marks a critical juncture, wherein rapid industrialization and economic advances have led to inequality and social issues (Chew 2018). For one, Singapore's first-world status readily lends itself to a globalized view of cultural openness, with expatriate workers making up a sizable demographic as non-resident figures tend to double each decade (Leong Chan-Hoong and Hong 2014, p. 56). Most recently, the Ministry of Manpower reports an excess of 1.3 million foreigners residing within Singapore (Ministry of Manpower 2019). Perhaps precisely because of, rather than despite, Singapore's global capitalist agenda that aims to attract a vibrant community (Chan 2008), cultural conservatism is heavily propounded by the national tenet of Shared Values, appropriated from Confucian philosophy, and disseminated within local schools that teach their students to value national interests over individual interests and rights (Tan 2012).

Turning attention to Koe's works, "Siren" is a short story that deals exclusively with the repugnant act of homosexual activity between a grown man and a transsexual. It focuses on the growing pains of Marl, first introduced as a child who is vilified in school. The school's backdrop serves as an educational center and social apparatus for ideological state values to be promulgated, internalized and supported. The narrator of the story finds himself coerced into a position of a bully, as he is pressured by his classmates to act out against ascribed discriminatory labels of "Pansy, wuss and faggot" (original italics, p. 174). As a result of the emotional trauma brought on by the school bullies, Marl fails to return to class and is quickly withdrawn from school by his peculiar father. Born to a lionhead and a fish (mermaid), the protagonist-narrator serves as the physical embodiment of Singapore's national icon of the Merlion-here, it serves as the primary cause of his shame rather than celebration. The story is divided into two parallel-running narratives: Marl and the narrator's episode in school as children and fourteen years later in a pub, and a tale about the lionhead as a hirsute sailor seduced by a mermaid. Father lionhead is abandoned by mother Siren, and thus the former brings up their son Marl as a single parent. As the story's conclusion suggests, lionhead's prostrate position whilst "tied down by both wrists" (p. 186) as he lays "painfully thin" on a hospital bed exemplifies his degraded state by "diagnostic categories" (Clare 2003, p. 154) both unhelpful and reductive. For producing a "faggot" of a son, he is rendered mad. Common to father and son is, thus, the experience of being wronged and shamed.

On the other hand, the story "The Ballad of Arlene and Nelly" features college female lovers who go their separate ways when one betrays the other to fulfill the social expectations of a heterosexual marriage. Readers learn as much about Arlene, the jilted lesbian partner, as they do Nelly—a figure exhibiting a "false-self system," to borrow Robert Laing's terminology. In this story, the narrator suggests that the underlying reason Nelly insinuates that her love affair with Arlene would end once college was finished (p. 191) is due to the former being "compulsively compliant to the will of others" (Laing 1965, p. 96), whilst the latter was neither willing nor ready to do so. In other words, Nelly shows herself to internalize ideological state values of Chinese majority Singapore, with both sets of parents being "Chinese-educated" and preaching heterosexuality for the biological reproduction of boys (pp. 198-99). In the gender-differentiated space of the bathroom, Nelly responds to Arlene's question about loving her groom with an unconvincing "Yes!" (original italics, p. 193), which is fake and forced because of the lack of happiness compared with Arlene's companionship (p. 200). In subsequent days of her heterosexual marriage, Nelly is unable to forgive her cheating husband and abandons their "placid" (p. 201) marriage. Contrasted to Nelly's hyper-conscious sense of her reality, Arlene demonstrates an experience of self whereby the true self is synchronous with her external behavior. In this body-self construct, Arlene's identity is expressed through her sexual fidelity and singular love for Nelly, which, in turn, expose a vulnerability marked against Singapore's prevailing standards of heteronormativity. Her dedication to stay loyal to Nelly is portrayed in the monosyllabic utterance of "No" (pp. 195-96), as her firm reply to questions of whether she sexually betrayed Nelly and entertained any lovers, including men, since they separated ways. Her subsequent admission of 
guilt in subscribing to Swedish porn underscores the terms of the unification of her body (physical) and self (emotive) - accentuating her affirmed certainty at having found "the only person she wanted to emote to in this lifetime" (p. 196), which is ironically a benchmark for state-sanctioned healthy monogamy. If Laing is correct in his observation that "the split in the experience of one's own being into unembodied and embodied parts is no more an index of latent psychosis than is total embodiment any guarantee of sanity" (1965, p. 68), then Arlene and Nelly's experience of self in their bodily indulgences as well as body-mind detachment marks the contingent status of heterosexual norms ascribed by the state, who defines and vilifies mad and bad behavior.

Even as Nelly may be regarded as the semi-conformist, while Arlene suffers the fate of abject insularity culminating in her physical departure, it is evident that the former encounters similar challenges as a lesbian. While the latter's introversion is marked by her watercolor paintings to deal with a painful social ostracization, the former's effortful assimilation traces her attempt to conform to society's demands. The sharply juxtaposed positions of Arlene and Nelly are evident:

What did Arlene paint? [ ... ] Arlene painted faceless women. That is, she painted woman who were looking away from her, who had hair obscuring their face, who were reclined so far back their faces were never visible, whose profiles were in shadow. (original italics, p. 196)

The above revelation highlights the visceral effects of Nelly's abandonment of Arlene. Furthermore, the "shadow[s]" in Arlene's paintings speak of the darkness that befall her psyche, troubled as it is by the dogmatic voices of society that she has chosen to depersonalize. In stark contrast, Nelly is characterized as level-headed, and therefore attempts to fulfill heteronormative conventions rather than resist them. As the narrator explains,

The truth of the matter was although Nelly and Arlene were in love as they knew it, there was also the understanding that this arrangement would hold only as long as they were in college together. Rather, this was what Nelly had always insinuated, and what kept Arlene up at night. (pp. 190-91)

Here, it is clear that Arlene's insomnia is triggered by Nelly's reminder of society's impingement into and curtailing of their intimate love affair, rendered as bad behavior by both sets of Chinese-educated parents who place "pressure valve[s]" (p. 199)] on their daughters to bear children. Consequently, Nelly inviting Arlene to her wedding reception both frustrates and infuriates the latter. Arlene's distress is apparent in her reaction to the attendees' toasting of happiness:

Everyone'd turned to [Arlene], she sounded like she was screaming in anguish; finally there was no more breath left in her, and she stopped short, feeling as if her throat and heart were on fire. (p. 192) [ ... ] Nelly, I'll let you walk away now. But if I ever see you again—I'll kill you. (original italics, p. 193)

At this point, the two eponymous characters are at odds against each other with no foreseeable resolution or reunion. The dissolution of identity enacted on Nelly is telling because it is the same kind implicated in Arlene's homosexual body. While Nelly achieves social inclusion through her newly married status-whose legitimacy is marked by her wedding reception's "video projection of congenial photos of the bride and groom with their old friends [while] [t]here were no pictures of Arlene and Nelly together" (p. 191), Arlene divisively remains an apprehended subject positioned on the periphery of Singaporean society.

And yet, Nelly's marriage and subsequent re-marriage to the same man marks her limited attempt at heteronormative identity and partial success at performing her role as a filial daughter to her parents, upon whom the nation's intentions for her are reflected. Her entry into heterosexual relations is notably arrested in her childless status (p. 201), thus unable to bring herself to consummate her legal marriage. It is clear that happiness eludes her in her heterosexual relations. In flashbacks to the time with Arlene, she is contrastingly seen to be happy. On a previous trip to Galapagos, the narrator admits "They 
[Nelly and Arlene] could walk hand in hand as two women, fearless, in Ecuador" (p. 197). Within a geopolitical space free from encoded definitions of Singaporean identity, the distant Galapagos Islands represent an alternative place and time, where their emotional state of "happiest" (p. 200) is realized. When beyond the reach of state apparatuses, ideological rather than repressive as punitive laws are not proactively enforced, no to little exhibition of a false or coerced self becomes necessary. Similarly, the intimation of a lack of fear accentuated by the physical absence from Singapore's geopolitical space signifies, in contrast, the social demand for a false self within their home country. When returning to Singapore for surgery to remove a breast tumor, Arlene's surgeon exits the operation theatre and declares "I'm done" (p. 199). Rather than signaling his successful completion of the operation, these words accompanied by his gesture of "holding his hands up" (p. 199) suggest that no more of the female subject of alterity is desired. In fact, the doctor's intervention results in the impossibility of Arlene and Nelly staying physically together as the patient eventually dies at his hands. Arlene's "burgeoning lump" (p. 188), the ostensible cause of her premature demise, is not only malignant but serves as a signifier of her entrapment within gender roles and the social expectations of heterosexuality. In this perspective, the lump exposes Arlene as a Singaporean non-subject with no legitimate place in Singapore's body politic. Her lack of social inclusion leads her to encrypt her losses and disguise her pain in personal drawings of mysterious faces that consistently "look away" (p. 195). Along this line, Arlene's verbal reluctance to articulate losses signifies the daily silence and repressed emotions of lesbians under the disciplining scrutiny of the state, as a proxy for the family who turns away from her and turns her away. As a culminating point, Arlene's conflicted subjectivity manifests itself in her failed participation within acceptable heterosexual relations. Unlike Nelly, she cannot boast of having attempted to forge heterosexual relations. Even as officially removed from the diagnostic category of mental illness, as demonstrated through Arlene and Nelly, homosexuals live with constant demands for their social conformity, or coerced self that fulfils the intentions of others for them. Such problems in living are epitomized by Nelly, whose fate is no better although she escapes death to which Arlene eventually succumbs. The former demonstrates that she is worse off, as she is made answerable to others' intentions for her conformed subjectivity while remaining alive in Singapore's nation-state.

Furthermore, state intervention by means of authorized psychiatric help is suggested in the schema of question and answer that structures Arlene and Nelly's personal narratives. Such a framing device mirrors the setup of psychodynamic therapy sessions that are characterized by a therapist's probing interjections. For instance, a question is posed "How long did it take Arlene's condition to deteriorate?" (original italics, p. 197). The narrator's answer "It took seven months before it became impossible to hide" (p. 197) assumes the voice of Nelly, who is now being "treated" as she recounts the protracted period Arlene concealed her "sickness" from family and medical staff. Using the lens of a psychiatric examination, the significance of her response lies in the necessity of hiding, which is inextricably intertwined with the undesirability of appearing-a survival strategy for creating an illusion of normality in public. Arlene's cancer is readily introduced in the question "Why didn't Arlene go to the doctor when the lump first appeared?" (original italics, p. 188) From the start of the story, the appearance of questionable illness embodied in her lump entails a symbolic disruption to the good social order. In other words, the physical manifestation of sickness positions Arlene as an unwanted subject in society, undesirable for her pathological constitution that necessitates the unsolicited intervention by a third party, comprising the state and family with their resort to medical officers. Moreover, it presents an excruciating dilemma between the choice for a feigned (false and conformist) identity, on the one hand, and an instinctive expression of an authentic (non-conformist) self, on the other hand. As a metaphor, the lump thereby signals Arlene's anomalous status as a homosexual. The presence of medical authorities in both the surgeon and psychiatrist, unsolicited by the patient, highlights the medicalization of the psyche amid socio-cultural influences that collectively produce a concealed sexuality, which the lump prefigures. Also, the eventual appearance of this tumor "on the left" (p. 188) breast suggests, at a psychosomatic level, that the brain's left side is simultaneously injured by a foreign-attacking tumor: "Leftwards [ ... ] was a jinx" (p. 188). Arlene's 
anxiety about the left side indicates her censuring of her deteriorating left-side brain associated with logic and reason, which are traits valued in pragmatic Singapore, contrasted to emotions and instinctive feelings controlled by the right side of the brain's cortex. In short, the insinuation that Arlene loses or damages her sense of pragmatism that would enable her to choose a normal heterosexual life justifies society's pathologization of her, with her left-positioning heart as the storehouse of love simultaneously obtruded by medical practitioners, state and society.

Furthermore, Arlene's lump's visibility betrays the limited possibility of hiding her true self beneath a physical veneer, and herein lies the main problem or struggle of living in Singapore. Hiding becomes a defensive means to suppress the indicators of what society regards as a "diseased mind" that marks the lesbian subject as badly different and a mad Other-both paradigms warranting the external counsel of the state. In the section "Did she get better?" Arlene's health yields at the hands of the surgical doctor, summoned on the scene to address her physical symptoms rather than emotional repression. It is noteworthy that she resists meeting the surgeon until her final days in the operation room, where her family members also gather outside. Even while signaling familial unity, this concluding scene consolidates the juxtaposition of "us versus them", by reiterating disparities between doctor and patient, parent and child, and parent and lover. First, the doctor's practice of medicalization is resisted as Arlene refuses to submit to a terminological reduction of her condition with a physical lump. Second, her parents' intentions for her are at odds with the free will she exercises when remaining unmarried. Lastly, even as Nelly is not a "kin", as the nurse outside the examination room determines, she shares a knowledge of Arlene in whom the dis-ease was not successfully cured. Nelly's loud vocalization as her voice "splic[es] through Arlene's mother's sobs and the doctor's jargon" (p. 199) exhibits her strong insistence at familiarization with her lover. Here, she reveals that Arlene is more than the sum of her family's wishes and patient to the surgeon. Her intimacy with, and knowledge of, Arlene prove she is privy to the real Arlene, who has hidden herself away from her parents and doctors. However, the eventuality of the lump's appearance and her being taken ill to the point of death testifies to the tenuousness of life, especially for homosexuals for whom state regulators and institutional powers threaten their existence.

In view of Freudian analysis of civilization as repressive with "a conflict between the demands of conformity and the demands of our instinctive energies, explicitly sexual" (Laing 1965), Koe's story "Alice, You Must be the Fulcrum of Your Own Universe," about a sexual affair between a girl and a married older woman with her subversive mantra "live for yourself" (original italics, p. 114), conveys the struggle between feigned and authentic selves. In the opening scene, a public display of homosexual affection is portrayed. Here, the physical act of non-inhibited homosexual energies is signaled through the female protagonists kissing in a capsule of the Singapore Flyer. Similar to the two lovers in "The Ballad of Arlene and Nelly," Alice and Jenny exemplify the challenges of resisting the institutional reduction of their sexuality to a kind of illness - both on medical and social grounds-due to their transgressive sexual desires. Alice, the narrator, shows herself to adopt the hegemonic lens when declaring "we don't have a plastic bag on us" (p. 111) with which to conceal their kissing from the prying eyes of the public. However, the two female lovers appear unhindered by the public openness in which they are expressing their love within the glass-windowed capsule of a national landmark-the Singapore "Eye" Flyer. At the point where Jenny admits to having last been passionately kissed at the age of eighteen, Alice evokes the presence of a mental health practitioner: "Do you need a doctor?" (p. 111). Her response points to Jenny's (homo)sexual energies that have been repressed due to her heterosexual marriage, thus giving rise to a need to re-evaluate her sexual pleasures as a tradeoff for social conformity. The added allusion to R. K. Narayan's "Under the Banyan Tree" ["The last time I was kissed for that long, I was eighteen, under a banyan tree" (original italics, p. 111)] accentuates her fear of speaking out as it recalls the silent Nambi of Somal. Here, the presence of fear denotes the attendant pressure to conform to a censored or silenced status of sexual subjectivity. In her intimate admission of, "I'm afraid of giving myself away, because I don't know what I am yet" (p. 114), Alice describes her anxiety about her categorical being established via prescriptive labeling and her objectified status. 
Her Singaporean "I" in this case is tested within the capsule of the Singapore Flyer or "Eye" (with it resembling the utterance of " $\mathrm{I}$ "). Restraining from expressing her sexual feelings for the heterosexually married Jenny when questioned by her mother (p. 115), she reveals her distress with the policing of her sexual identity within the public sphere as well as the familial home. In this sense, Jenny's adage of "we are always in a process of becoming" (original italics, p. 114) rings true for Alice. It delimits the appealing possibilities of transgressing the expectations of the family and state. For Alice, the anxiety in articulating "simple natural love between [homosexual] human beings" (Laing 1965) is encapsulated by the antagonism proffered by society's lens compared with the individual's view of embodied homosexuality.

Considering Alice and Jenny's sexual feelings for each other are curtailed within the family home and national spaces and self-regulated through their internalization of social norms, frames of loss appear prevalent. Loss signals the problems encountered with social acceptance, inclusion and participation when truthful to themselves and the rest of their society, including family members and the male spouse. Ambiguity and self-doubt taint their emotional connection to each other as Jenny shares, "Alice? I think I'm a little in love with you. It isn't your fault" (original italics, p. 117). It is interesting to note that this declaration of love is framed by a question marking an uncertainty, followed by a weak declarative statement when "think" is employed. Also, the quantifiable measure of scarcity is employed in "little", which is contrasted to the abundance signaled in declarations of love that use "much" or "very" to express a positive physical attraction. Significantly, Jenny absolves Alice of blame to suggest that the sexual attraction is socially undesired and critically censured. As a source of "nuisance" (Friedenberg 1973, p. 44), homosexual feelings of attraction come to be regarded as the reason as to why "life is difficult" (original italics, p. 124). For Jenny, it reminds her of what it is that she is missing or has lost; as she explains to Alice, "Life is difficult because in order to progress we have to come to terms with the things we do not have" (original italics, p. 124). The façade of heterosexual marriage that Jenny shares with her husband, who is similarly misguided as he indignantly claims she has not changed since having known her "[at] sixteen" (p. 122), is part of the artifice as well as sacrifice for achieving progress-or social mobility—in life. When confessing that life with Alice is comparatively "easy", Jenny thus betrays the difficulty in keeping up with social norms that fall beyond the lovers' private space. Like Nelly, Jenny's marriage is child-less because of her decision to "tie my tubes when I was thirty" (original italics, p. 114). Her disinclination for children and aversion to the heterosexual norm preclude her social participation. Hence, any attempt at partially attaining a heterosexual status is at the expense of individual subjectivity, typified by biological and social losses that transform into subjective gains when self-choices rather than false selves are asserted.

\section{Conclusions}

To sum up, the losses encountered by deviant Singaporean subjects are clearly framed using the ruling class' ideology of normative values, leading to social stigma against non-heterosexual figures and the social reduction of embodied "ill[ness] with depression" (Burton 2015a, p. 107) within social pariahs deemed as "failures" or "losers" (Burton 2015a, p. 106). Whilst, for Althusser, cultural apparatus may be subsumed under ideological state apparatuses (Althusser 2014, p. 248), Ministry of Moral Panic serves as a literary platform to expose and champion cultural differences away from the state's cultural homogeneity, marked in the state's dictates of power to control the nation's people and sexual behaviors. Ronald Laing and other anti-psychiatry proponents emphasize the practice of psychiatry as "repressive, coercive, political rather than psychological in that it is really a means of controlling people and putting those who make nuisances of themselves out of the way or destroying their capacity to be their own obnoxious selves" (Friedenberg 1973, p. 44). Such commentators offer critiques of the mad label ascribed to depressed and homosexual subjects by drawing on the state's investment in medical psychiatry, thus stimulating a controversy about the default to psychiatry "to control the wicked" (Szasz 1961). Counter-responses to their critiques have included charges against anti-psychiatrists of right-wing libertarianism, where left-liberal progressive analysts "believ[ing] 
that they [are] treating real diseases, [and] never voic[ing] objections against psychiatric coercions" (Schaler 2004, p. 23) are undermined. Amid ongoing debates on the state, family and medical institutions as stakeholders in the psychiatric diagnosis, Koe's work posits itself as cultural apparatus by articulating human variety in the suffering caused by societal structures that intervene into the lives of citizen-subjects. As institutionalized outcasts, her characters are victims to state erasure, where their sense of subjectivity is diminished. However, in transgressing the ideology of the ruling class, they demonstrate subjective agency via the resumption of mental faculties discounted by medicalization. As such, Ministry of Moral Panic offers a critique of state-ascribed depression and sexual citizenship, as it underscores subjective gains within the personal narratives of Singaporeans, whose stories about their purported madness gain emphatic resonance with their readers.

Funding: This research received no external funding.

Conflicts of Interest: The author declares no conflict of interest.

\section{References}

Althusser, Louis. 2014. On the Reproduction of Capitalism: Ideology and Ideological State Apparatuses. London and New York: Verso.

Arnold, Matthew. 1961. "Equality", Poetry and Criticism or Matthew Arnold. Edited by A. Dwight Culler. Boston: Houghton and Mirrin Company.

Au, Alex. 2009. Prime Minister's Speech. Global Rights Commonwealth. Stage 1. Appendix 3. Available online: https://alexau.wordpress.com/2009/10/03/global-rightscommonwealth-stage-1-appendix-3/ (accessed on 8 January 2019).

Brooks, Ann, and Lionel Wee. 2011. Regulating Sexual Citizenship in Singapore. Available online: https: //www.opendemocracy.net/ann-brooks-lionel-wee/regulating-sexual-citizenship-in-singapore (accessed on 8 January 2019).

Burton, Neel. 2015a. The Meaning of Madness. Sandford-on-Thames: Acheron Press.

Burton, Neel. 2015b. When Homosexuality Stopped Being a Mental Disorder. Psychology Today. Available online: https://www.psychologytoday.com/intl/blog/hide-and-seek/201509/when-homosexuality-stoppedbeing-mental-disorder (accessed on 8 January 2019).

Chan, Kenneth. 2008. Gay Sexuality in Singaporean Chinese Popular Culture: Where Have All the Boys Gone? China Information 22: 305-29. [CrossRef]

Chew, Agnes. 2018. Singapore: A Prosperous, Equal and Happy Society? Singapore Policy Journal. October 8. Available online: http://spj.hkspublications.org/2018/10/08/singapore-a-prosperous-equal-andhappy-society/ (accessed on 8 January 2019).

Clare, Anthony. 2003. Psychiatry in Dissent: Controversial Issues in Thought and Practice. London: Routledge.

Cooper, David. 1989. Introduction. In Foucault: Madness and Civilization: A History of Insanity in the Age of Reason. Translated by Richard Howard. London and New York: Routledge.

Dammann, Eric J. 1997. The Myth of Mental Illness: Continuing Controversies and Their Implications for Mental Health Professionals. Clinical Psychology Review 17: 733-56. [CrossRef]

Detenber, Benjamin H., Shirley S. Ho, Rachel L. Neo, Shelly Malik, and Mark Cenite. 2012. Influence of Value Predispositions, Interpersonal Contact, and Mediated Exposure on Public Attitudes towards Homosexuals in Singapore. Asian Journal of Social Psychology 16: 18-96. [CrossRef]

Detenber, Benjamin H, Mark Cenite, Shuhua Zhou, Shelly Malik, and Rachel L. Neo. 2014. Rights versus Morality: Online Debate about Decriminalization of Gay Sex in Singapore. Journal of Homosexuality 61: 1313-33. [CrossRef] [PubMed]

Foucault, Michel. 1978. History of Sexuality. Volume I: An Introduction. Translated by Robert Hurley. New York: Pantheon Books.

Foucault, Michel. 1982. The Subject and Power. In Power: Essential Works of Foucault 1954-1984. Translated by Robert Hurley. New York: The New Press, vol. 3.

Friedenberg, Frank Kermode Edgar Z. 1973. Laing. Fontana Modern Masters. Edited by Frank Kermode. London: Fontana/Collins. 
Gwee, Kenji. 2017. Psychology and psychiatry in Singapore courts: A baseline survey of the mental health landscape in the legal arena. International of Law and Psychiatry 52: 44-54. [CrossRef] [PubMed]

Heng, Geraldine, and Janadas Devan. 1995. State Fatherhood: The Politics of Nationalism, Sexuality and Race in Singapore. In Bewitching Women, Pious Men: Gender and Body Politics in Southeast Asia. Edited by Aihwa Ong and Michael G. Peletz. Berkeley: University of California Press.

Koe, Amanda Lee. 2013. Ministry of Moral Panic. Singapore: Epigram Books.

Koe, Amanda Lee. 2016. Interview. From British Council Singapore Arts. Poets and Writers. Available online: https://www.pw.org/content/amanda_lee_koe (accessed on 8 January 2019).

Kuah, Khun Eng. 2018. Social Cultural Engineering and the Singaporean State. Singapore: Springer.

Laing, Ronald David. 1964. Is Schizophrenia a Disease? International Journal of Social Psychiatry 10: $184-93$. [CrossRef] [PubMed]

Laing, Ronald David. 1965. The Divided Self: An Existential Study in Sanity and Madness. London: Penguin.

Lee, Hsien Loong. 2007. Full Parliamentary Speech of PM Lee Hsien Loong in 2007 on Section 337A. The Straits Times. October 24. Available online: https://www.straitstimes.com/politics/full-parliamentary-speech-bypm-lee-hsien-loong-in-2007-on-section-377a (accessed on 15 March 2019).

Lemma, Alessandra. 1996. Introduction to Psychopathology. London: Sage Publishing.

Leong Chan-Hoong, Patrick Rueppel, and Daniel Hong. 2014. Managing Immigration and Integration in Singapore. In Migration and Integration: Common Challenges and Responses from Europe and Asia. Edited by Wilhelm Hofmeister, Patrick Rueppel, Yves Pascouau and Andrea Frontini. Singapore: Konrad-Adenauer Stiftung.

Lim, Kean Fan. 2004. Where Love Dares (Not) Speak Its Name: The Expression of Homosexuality in Singapore. Urban Studies 41: 1759-88. [CrossRef]

Lim, Eng-Beng. 2014. Brown Boys and Rice Queens: Spellbinding Performance in the Asias. New York: New York University Press.

Low, Patrick Kim Cheng. 2006. Father leadership: The Singapore Case Study. Management Decision 44: 89-104. [CrossRef]

Maisel, Eric R. 2016. Interview with Joanna Moncrieff on the Myth of the Chemical Cure: On the Future of Mental Health. Psychology Today. The Future of Mental Health: Interview Series. Available online: https://www.psychologytoday.com/us/blog/rethinking-mental-health/201602/joanna-moncrieff-themyth-the-chemical-cure (accessed on 8 January 2019).

Mills, Charles Wright. 1963. The Cultural Apparatus. In Power, Politics, and People: The Collected Essay of C. Wright Mills. New York: Oxford University Press.

Ministry of Manpower, Singapore. 2019. Foreign Workforce Numbers. March 14. Available online: https: //www.mom.gov.sg/documents-and-publications/foreign-workforce-numbers (accessed on 8 January 2019).

Mokhtar, Faris. 2018. The Big Read: With a house still divided over 377A, time to seek common ground. Channel News Asia. September 18. Available online: https://www.todayonline.com/big-read/big-read-house-stilldivided-over-377a-time-seek-common-ground (accessed on 15 March 2019).

Moncrieff, Joanna. 2013. Lecture at the Centre for Global Humanities. Available online: https://www.youtube. com/watch?v=KBPPtyb4TvA (accessed on 8 January 2019).

Muliyala, Krishna Prasad, and Mathew Varghese. 2010. The Complex Relationship between Depression and Dementia. Annals of Indian Academy of Neurology 13: S69-73. [CrossRef] [PubMed]

Nair, Hri Kumar. 2007. Section 377A is inconsistent: PAP MP Hri Kumar. The Online Citizen. October 23. Available online: https:/www.theonlinecitizen.com/2007/10/23/section-377a-is-inconsistent-pap-mp-hrikumar/ (accessed on 8 January 2019).

Naruse, Cheryl Narumi, and Weihsin Gui. 2016. "Singapore and the Intersections of Neoliberal Globalization and Postcoloniality". Interventions: International Journal of Postcolonial Studies 18: 473-82. [CrossRef]

Ong, Andrea. 2013. Opposition Politician Wijeysingha is First Politician to Say He's Gay. The Straits Times, July 3.

Ong, Justin. 2018. Singapore Society has to Decide which Direction It Wants to Take on Laws Against Gay Sex: Shanmugam. Channel News Asia. September 7. Available online: https://www.channelnewsasia.com/ news/singapore/singapore-gay-sex-law-377a-shanmugam-society-has-to-decide-10693926 (accessed on 8 January 2019).

Oswin, Natalie. 2014. Queer Time in Global City Singapore: Neoliberal Futures and the 'Freedom to Love'. Sexualities 17: 412-33. [CrossRef] 
Rippere, Vicky. 1994. Depression. In The Handbook of Clinical Adult Psychology. Edited by Stan Lindsay and Graham Powell. London: Routledge.

Schaler, Jeffrey A., ed. 2004. Szasz Under Fire: The Psychiatric Abolitionist Faces his Critics. Chicago: Open Court Publishing.

Shen, Rujun. 2014. Wear white to protest pink gay rally, religious groups say. Reuters. Available online: https://www.reuters.com/article/us-singapore-protests/wear-white-to-protest-singapore-pink-gayrally-religious-groups-say-idUSKBNOEYOSB20140623 (accessed on 8 January 2019).

Sikuska. 2016. Ministry of Moral Panic: Q\&A with Short Story Writer Amanda Lee Koe. Available online: http:// www.ubudwritersfestival.com/blog/ministry-moral-panic-qa-short-story-writer-amanda-lee-koe/ (accessed on 8 January 2019).

Silverstein, Charles. 1996. History of Treatment/The Medical Treatment of Homosexuality. In Textbook of Homosexuality and Mental Health. Edited by Robert Paul Cabaj and Terry S. Stein. Washington: American Psychiatric Publishing.

Singapore: Court Ruling a Major Setback for Gay Rights. 2014. Human Rights Watch. Available online: https://www. hrw.org/news/2014/10/29/singapore-court-ruling-major-setback-gay-rights (accessed on 8 January 2019).

Sunday Times. 2002. Available online: https://yawningbread.files.wordpress.com/2013/02/pic_201302_21.pdf (accessed on 8 January 2019).

Szasz, Thomas S. 1961. The Myth of Mental Illness. American Psychologist 15: 113-18. [CrossRef]

Tan, Kenneth Paul. 2003. Sexing Up Singapore. International Journal of Cultural Studies 6: 403-23. [CrossRef]

Tan, Charlene. 2012. "Our Shared Values" in Singapore: A Confucian Perspective. Educational Theory 62: 449-63. [CrossRef]

Wayne, Arnold, and International Herald Tribune. 2003. Quietly, Singapore Lifts Its Ban on Hiring Gays. New York Times. July 5. Available online: https://www.nytimes.com/2003/07/05/news/quietly-singapore-lifts-its-banon-hiring-gays.html (accessed on 8 January 2019).

Wong, Jane Yeang Chui. 2016. Oscar Wilde in Singapore: Ambivalence, Enforcement, and the Criminalization of Homosexuality. Sexuality and Culture 20: 504-24. [CrossRef]

Woon, Walter. 2014. Walter Woon, Tommy Koh differ on 377A anti-gay sex law at NUS Forum. The Straits Times. September 18. Available online: https://www.straitstimes.com/singapore/walter-woon-tommy-koh-differon-377a-anti-gay-sex-law-at-nus-forum (accessed on 8 January 2019).

Yeoh, Paul. 2006. Writing Singapore Gay Identities: Queering the Nation in Johann S. Lee's Peculiar Chris and Andrew Koh's Glass Cathedral. The Journal of Commonwealth Literature 41: 121-35.

Yue, Audrey, and Jun Zubillaga-Pow, eds. 2012. Queer Singapore: Illiberal Citizenship and Mediated Cultures. Hong Kong: Hong Kong University Press. 